Témoigner Témoigner. Entre histoire et mémoire

Getuigen Revue pluridisciplinaire de la Fondation Auschwitz

$125 \mid 2017$

Histoire et mémoire de la persécution des

homosexuel-le's par les nazis

\title{
Inleiding. De vervolging van homoseksuelen door de nazi's
}

Présentation. Histoire et mémoire de la persécution des homosexuel-le-s par

les nazis

\section{Régis Schlagdenhauffen}

Traducteur : Gorik de Henau

\section{CpenEdition}

\section{Journals}

Édition électronique

URL : https://journals.openedition.org/temoigner/6339

DOI : 10.4000/temoigner.6339

ISSN : 2506-6390

Cet article est une traduction de :

Présentation. Histoire et mémoire de la persécution des homosexuel-le-s par les nazis - URL : https:// journals.openedition.org/temoigner/6319 [fr]

Éditeur :

Éditions du Centre d'études et de documentation Mémoire d'Auschwitz, Éditions Kimé

Édition imprimée

Date de publication : 1 octobre 2017

Pagination : 60-71

ISBN : 978-2-930953-01-4

ISSN : 2031-4183

Référence électronique

Régis Schlagdenhauffen, «Inleiding. De vervolging van homoseksuelen door de nazi's», Témoigner. Entre histoire et mémoire [Online], 125 | 2017, Online op 24 décembre 2021, geraadpleegd op 03 février 2022. URL: http://journals.openedition.org/temoigner/6339; DOI: https://doi.org/10.4000/temoigner. 6339 


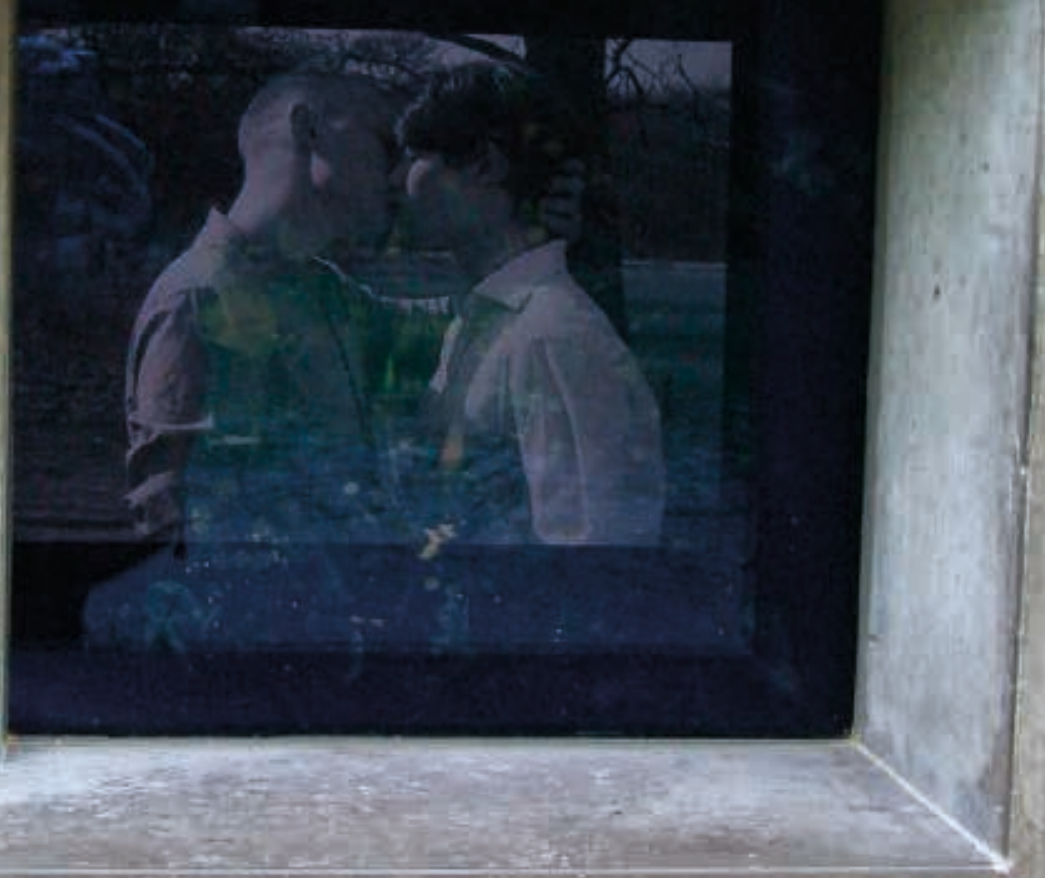

\section{DE}

VERVOLGING VAN HOMOSEKSUELEN DOOR DE NAZI'S

Dankzij het toegenomen aantal studies over het onderwerp is de afgelopen jaren onze historische kennis gegroeid over de vervolging en deportatie van homoseksuelen door de nazi's.

In dit dossier geven we het woord aan zowel ervaren als jonge onderzoekers. $Z_{i j}$ werpen een licht op het bijzondere lot van vrouwelijke en mannelijke homoseksuelen tijdens de Tweede Wereldoorlog, en bestuderen hoe de herinnering aan deze episode evolueerde na de oorlog.

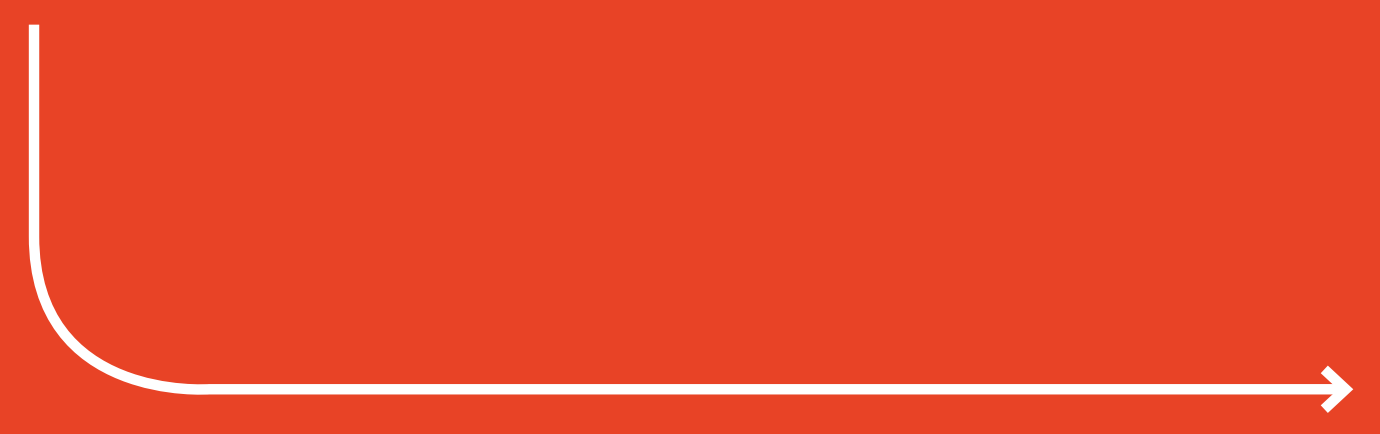




\section{Voorstelling van de artikels}

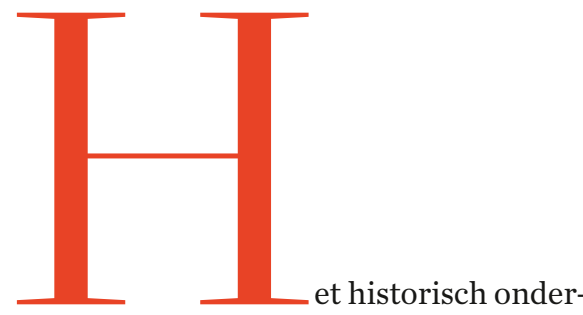

zoeknaar de vervolging van homosekstelen tijdens de Tweede Wereldoorlog in Europa wordt steeds accurater. Hoewe er nog geen overkoepelende Europes studie over de problematiek bestaat, willen we in deze inleiding een algemeen overzicht bieden van de huidige stand van het onderzoek. We bestede bijzondere aandacht aan lopende studies, waarvan sommige met een artike in dit nummer aan bod komen.

Vervolgens bestuderen we in Europees verband: de soorten vervolging van homoseksuelen gedurende de Tweed Wereldoorlog, hun uiteenlopende ervaringen in de concentratiekampe en tot slot de vormen van verzet, $d$ zeldzame vrijheden en meer algemeen de progressieve wetgeving in bepaald landen. Hoewel het naziregime voo heel wat personen in verschillende maatschappelijke groepen gelijkston met absolute gruwel trachtten sommig staten toch doelbewust de individuele vrijheden te beschermen, althans wat seksuele geaardheid betreft.
De vervolging van homoseksuelen werd in de loop der jaren steeds beter gedocumenteerd. Dat blijkt uit de vie artikelen in dit dossier.In het eerste wijst Florence Tamagne erop dat de nazivervolging van Duitse homoseksuelen twaalf jaar (1933-1945) duurde. Ze ging gepaard met meer dan 100000 arrestaties en nam nooit eerder gezien vormen aan. Het nationaalsocialistische systeem wilde homoseksualiteit uitroeien via een combinatie van preventieve en dwangmaatregelen: verplichte medische behandelingen, castratie, veelsoortige experimenten. Daardoo werden de levens van tienduizenden vrouwen en mannen kapotgemaakt; ze werden naar gevangenissen en concentratiekampen gestuurd en slechts enkeen overleefden het

Vervolgens stelt Claudia Schoppmann een synthese voor van het onderzoek naar lesbische vrouwen onder het nazi-juk. Ze baseert zich op getuigenissen van deportatieoverlevenden en werpt licht op een levendige lesbische subcultuur in de concentratiekampen, maar ook op de spanningen binnen een afgesloten, eenslachtige wereld, waarin homoseksuele vrouwen om verschillende redenen vaak op een zijspoo werden gezet. Via dit artikel krijgje ook zicht op een wereld die niet vrij was van (vooral seksueel) geweld.

In zijn artikel beschrijft Jean-Luc Schwab hoe de onderdrukking van homoseksualiteit tijdens de Tweede Wereldoorlog in Frankrijk werd aangepakt. In het zogenaamde 'vrije' Frankrijk, in bezet Frankrijk en in geannexeerd Frankrijk (de Elzas en Moselle) waren drie verschillende vormen van gerechtelijke en buitengerechtelijke vervolging van toepassing. In het eerste geval maakte de staat vanaf 1940 gebruik van administratieve opsluiting. In bezet gebied kon elke Franse burger die intieme relaties had met een soldaat van het bezettingsleger worden vervolgd door een speciale Duitse rechtbank, en wel krachtens artikel 175 van het strafwetboek van het Derde Rijk ter beteugeling van 'tegennatuurlijke' betrekkingen. In ingelijfd Frankrij ten slotte gebruikte het naziregime zowel buitengerechtelijke als gerechtelijke vervolging in het raam van de Gleichschaltung (gelijkschakeling) van deze drie departementen in het oosten van Frankrijk. Uiteindelijk werden niet minder dan 370 homoseksuele mannen het slachtoffer van dit beleid; de meesten werden opgesloten in het speciale heropvoedingskamp Schirmeck.

Sam Seydieh, die onlangs zijn doctoraatsverhandeling in de sociologie verdedigde, laat in zijn artikel zien hoe er een specifiek engagement ontstaat in militante LGBT-kringen (lesbisch, gay, bi- en transseksueel) op basis van verschillende herinneringsvormen aa de homodeportatie (getuigenissen, sporenonderzoek, herdenkingen). Hoe zee de gemeenschap ook is geèvolueerd en hoe groot de onderlinge verschille ook mogen zijn, zo stelt de auteur, he militante milieu blijft een plaats waabinnen verschillende aspecten van de herinnering kunnen samenkomen: 'tweedegraadsherinneringen' van activisten, historische herinnering van activisten rond een gemeenschappelijk verleden en gemeenschappelijke herinneringen aan de strijd. Via zijn artike kunnen we begrijpen hoe belangrijk de militante socialisering is voor het doorgeven van de herinnering. De drijfvere van dit engagement zijn enerzijds te vinden in de institutionele context en anderzijds in de individuele loopbaa van activisten.

\section{Stand van \\ het onderzoek}

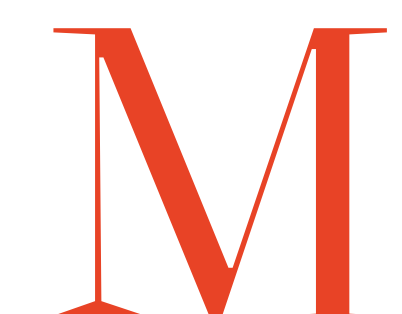

L eteen na de oorlogpubliceerden activisten hun eerste boeken en verslagen over het lot van homoseksuelen tijdens het naziregime, waarmee de krijtlijnen voor het collectieve geheugen werden uitgezet. Het speerpunt daarvan was het tijdschrift Levensrecht, uitgegeven in Amsterdam. Ondanks de onnauwkeurigheden en de soms militante toon van de artikelen en getuigenissen vormde het toch de basis voor de historische werken die daarna zouden verschijnen (Schlagdenhauffen 2011). Toen in de jaren vijftig in Duitsland artikelen verschenen in tijdschriften van homoseksuele verenigingen werd de weg gebaand voor de eerste schoorvoetende boekpublicaties in de jaren zestig. Das Große Tabu (1967) was het product van een conservatieve tijd. In dit werk trachtte de Duitse seksuoloog Willhart Schlegel in de eerste plaats de schijnwerpers te richten op homohaat, en dan vooral zoals die op nooit eerder geziene wijze tot uiting was gekomen bij de nazivervolging van homoseksuelen. Dankzij mei 68, een 
beloftevol moment waarop in verschillende Europese landen emancipatiegroepen en -verenigingen van homo's en
lesbiennes werden opgericht, ontstond een wil tot weten. In hun algemen strijd om vergeten verhalen uit de 'offciële geschiedenis' onder de aandach te brengen toonden homo-activiste ook meer interesse voor de specifiek lijdensweg van hun voorgangers. Vana de jaren zeventig mengden ze zich steeds vaker in het debat en gingen $z$ zich de roze driehoek toe-eigenen die gedeporteerde homoseksuelen in de kampen droegen.

De publicatie van de memoires van Heinz Heger was daar niet vreemd aan, want via dit eerste getuigenis van ee gedeporteerde homoseksueel konde de activisten van homoseksuele bevrijdingsbewegingen zich voor het eerst met een slachtoffer identificeren. In de in 1972 verschenen bestseller $D$ mannen met de roze driehoek werd het relaas gedaan van de gedeporteerd oostenrijkse homoseksueel Hein z Heger. Daarna volgde de sociologische en historische studie Seminar: Gesellschaft und Homosexualität van Rütger Lautmann. Via een kwantitatieve studie toonde de auteur aan dat homoseksuelen in de concentratiekampen vanwege verschillende sociale elementen ee veel lagere levensverwachting hadde dan 'heteroseksuele' gevangenen (Lautmann 1977, 300-365). Daarna ging het aantal publicaties in stijgende lijn. W vermelden twee doctoraatsverhandelingen. In Homosexuelle unter dem Hakenkreuz (1990) maakte Burkhar Jellonek gebruik van de Gestapo-archieven om een vergelijking te maken tussen de vervolging in een grote Duits metropool (Düsseldorf), een middelgrote stad (Würzburg) en een landelijk gebied (de Palts-streek). En Claud Schoppmann behandelde deze kwesti voor het eerst via de gender-invalshoek in haar verhandeling uit 1997, die vandaag nog altijd geldt als de referentie bij uitstek betreffende lesbische vrouwen onder het Derde Rijk. Deze werken effenden het pad voor een reeks publicaties die exclusief gewijd waren aan de geschiedenis van Duitse homoseksuelen in het Derde Rijk, bijvoorbeeld die van Thomas Rahe (1999) en Olaf Mussmann (2000). Daarnaast verschenen, onder de impuls van een groep Nederlandse onderzoekers (Koender 1996), de eerste buitenlandse studie naar homoseksuelen in de door de nazi' bezette en ingelijfde gebieden. Tot slo publiceerde de historicus Günter Grau in 2004 een werk dat ook een referentie zou worden. Via administratiearchieven schetste hij hoe de nazi's in Duitsland en in bepaalde ingelijfde gebieden stapsgewijs de vervolging van homoseksuelen organiseerden.

Behalve wetenschappelijke literatuur zijn er ook de getuigenissen van homoseksuelen die werden vervolgd tijdens het Derde Rijk en meer algemeen de Tweede Wereldoorlog. Sommige daarvan zijn autobiografisch van aard, bijvoorbeeld die van de reed genoemde Oostenrijker Heinz Hege (1972), Pierre Seel (in 1994 gepubliceerd met medewerking van dejournalist Jean Le Bitoux) en Rudolph Brazda. Die laatste maakte in juni 2008, op 95-jarige leeftijd, wereldkundig dat hij een gedeporteerde homoseksueel was; Jean-Luc Schwab schreef zijn biografie die in 2010 in het Frans verscheen. Ze sloot aan bij een reeks gebundelde getuigenissen die door Duitse collega's op schrift werden gesteld en uitgegeven. In dit verband vermelden we het boek van Lutz van Dijk uit 1992, met elf verhalen van homoseksuelen die de oorlog overleefden. Andreas Sternweiler stelde da weer de reeks Lebensgeschichten samen met het levensverhaal van vier Duits homoseksuelen: de fotograaf Albrech Becker, de padvinder Heinz Dörmer, de literatuurprofessor Richard Plant en de kunsthistoricus Christian Adol Isermeyer.

Dit overzicht zou niet volledig zij zonder de theatrale, filmische en literaire producties en de recentste Franstalige publicaties. Zo is Bent van Marti Sherman het toneelstuk bij uitstek over de nazivervolging van homoseksuelen (vgl. Hammermeister 1997). Het gin in 1979 in première in Londen, werd in 1980 opgevoerd in New York en in 198 in Parijs. In 1999 volgde de documentaire Paragraph 175 van Rob Epstein en Jeffrey Friedman. ${ }^{1}$ Dichter bij hui verschenen onlangs twee literaire werken in het Frans. Het eerste, Les guéri van Olivier Charneux (2016), gaat ove de ervaringen van de Deense arts Car Vaernet die medische experimenten uitvoerde op groepen homoseksuelen in het kamp Buchenwald. In he tweede, Je suis en vie et tu ne m'entend pas van DanielArsand, keert een zekere Klaus na zijn deportatie terug naar een wereld waarin hij door niemand mee wordt opgewacht. Verder verschenen er een aantal geschiedkundige werke in het Frans, wat wijst op de actuel belangstelling voor de kwestie van de 'homoseksuele deportatie'. We denken dan aan Le III Reich et les homosexuels van Thomas Rozec (2011) en de studie van Mickaèl Bertrand (2011) en Régi Schlagdenhauffen (2011, 2017).

In wat volgt, vatten we de belangrijkste resultaten van die werken samen Op die manier willen we licht werpen op het complexe karaktervan de vervolgin van homoseksuelen tijdens de Tweede Wereldoorlog, maar ook op bepaalde vrijheden en de progressieve wetgeving die tijdens die periode in enkele Europese landen werd ingevoerd.

\section{Vervolging}

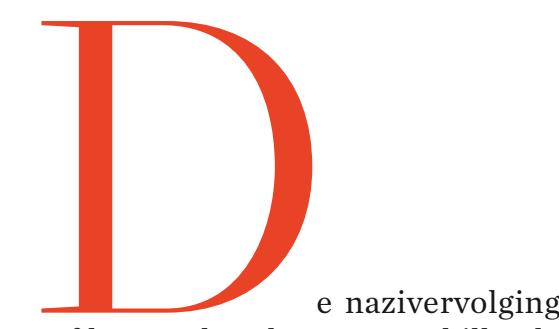

trof bomoseksuelen op verschillende monien op verschillende en nationaliteit. In hetalgemeen richtte het naziregime zich eerder op mannen dan op vrouwen : het nam verder homoeksuelen in Duitsland en de geannexeerde gebieden in het vizier terwij het zich daar in de bezette gebieden maar minimaal mee bezighield. Ook werden niet alle Europese homoseksuelen gedeporteerd. De geschiedenis en bijzonderheden van die vervolging in Duitsland komen aan bod in de artielen van Florence Tamagne en Claudia Schoppmann.

In Oostenrijk en Nederland, twee staten onder nazigezag, toonde het nazisysteem dat het zich kon aanpassen aan de omstandigheden. Na de Anschluss in 1938 werd Oostenrijk in het Derde Rijk opgenomen maar het Oostenrijkse recht bleef er van kracht. In tegenstelling tot Duitsland waren homoseksuele relaties verboden ongeacht het geslacht van de partners, dit het Oostenrijkse strafwetboek. Om 
die reden telt Oostenrijk van alle doo het Reich ingelijfde staten het grootste aantal lesbische nazislachtoffer Volgens Angela Mayer (2002) werde er tientallen daadwerkelijk opgepakt en veroordeeld. De meeste vervolgd lesbiennes werden opgesloten in concentratiekampen of arbeidsheropvoedingskampen (Arbeitserziehungslager) of nog in psychiatrische instellingen. I Wenen werden tussen 1938 en 194379 vrouwen veroordeeld krachtens artikel 129, tegenover 1400 mannen tijde dezelfde periode (Kirchknopf 2017).

Hoewel in Nederland homoseksuele betrekkingen tussen instemmende volwassenen niet verboden waren, had de Nederlandse politie sinds 1920 toc de gewoonte om de identiteit van mensen met homoseksuele praktijken in speciale bestanden op te nemen (Koenders 2002,266).Pieter Koenders, auteur van een studie over de bestraffing va homoseksualiteit in bezet Nederlan beschrijft hoe het Duitse bezettingsleger op 31 juli 1940 een naziverordenin afkondigde waardoor homoseksuel relaties tussen instemmende volwassenen konden worden bestraft met ee gevangenisstraf van vijf jaar, naar he model van artikel 175 van het Duits strafwetboek. Dat was een aanvullin op artikel 248a van het Nederlandse strafwetboek, waarin homoseksuele betrekkingen tussen meerder- en minderjarigen verboden werden. Maa omdat de verordening van de bezetter kwam, toonde de Nederlandse politi zich niet bijzonder behulpzaam in het afdwingen ervan.

Als gevolg daarvan veranderden de nazi's van strategie en richtten in De Haag een centraal bureau op voor de registratie van homoseksuelen. Om de communicatie met de politie van he Rijk te stroomlijnen werd het coderingssysteem bovendien afgestem op dat van Duitsland (Koenders 2002 269). Vanaf 1943 zien we in het organisatieschema van de Nederlandse zedenpolitie een centrale voor de bestrijding van homoseksualiteit. $\mathrm{Op}$ die manier werden vier doelstellingen van de bezetter gerealiseerd: het verdwijnen van homoseksuele verenigingen, de strafrechtelijke veroordeling van (mannelijke) homoseksualiteit het registreren van als homoseksuee bestempelde personen en tot slot he oprichten van speciale politiebrigade voor de bestrijding van homoseksualiteit. Aangaande de bestraffing van homoseksuelen in Nederland komen we uiteindelijk tot volgende cijfers: 138 voorgeleidingen tussen 1940 en 1943 krachtens de ordonnantie 81/40, 90 veroordelingen en 10 opsluitingen in psychiatrische ziekenhuizen. Daarnaas werden 164 mannen voorgeleid wegens schending van artikel 248 bis, waarvan 77 tot een gevangenisstraf werden veroordeeld (Grau 2004,270). Tot slot vermeldt Koenders dat bepaalde personen weliswaar niet voor het gerecht werden veroordeeld, maar toch vervolgd werden vanwege hun homoseksualiteit; het betreft zonder uitzondering Joden Zo werden in 1942 drie mannen en een vrouw gearresteerd, vervolgens gedede Endlösung (Koenders 1996).

\section{Homoseksuelen in de kampen}

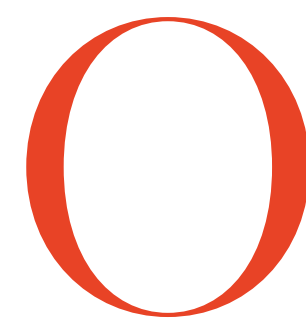
dat ongerer 50000 mack toont het nazirechtssysteem werden veroordeeld tot gevangenisstraffen, verbeteringsgestichten en werkkampen Tussen de 5000 en 10000 mannen werden vanwege homoseksualiteit in concentratiekampen opgesloten. Maar da vormden de homoseksuelen een statis tische minderheid; ze vertegenwoordigden minder dan eén procent van de gevangenen. Ze werden geografisch en sociaal gescheiden van hun kamerade en waren het slachtoffer van de SS é hun medegevangenen. De heersende homofobie in de kampen leek zo ee weerspiegeling van de homohaat in de samenleving. Homoseksuelen door hu heteroseksuele kameraden als eerste aangewezen voor overplaatsing naar die commando's en kampen waar de woonen werkomstandigheden het zwaarst waren. Door het homoseksuele etike waren deze mensen dan ook nog een voorbestemd om te dienen als proefkonijn: Castratie in Sachsenhausen, "normaliseringstesten' in Ravensbrück, 'hormoontherapie' in Buchenwald. In vergelijking met de andere groepen Duitse gevangenen was de levensverwachtingvan homoseksuelenveel lager zoals het ook onwaarschijnlijk was datze ooit zouden worden vrijgelaten. Van de vrijgelaten homoseksuelen werd bovendien een aanzienlijk aantal onder dwang ingelijfd bij de Wehrmacht of bijzondere SS-bataljons (vooral na 1942). Toch zijn er zeldzame gevallen bekend van homoseksuelen die zich in de kamphiërarchie wisten op te werken. Zij lijken zich te hebben gedragen als andere gevangenen met een zekere rang en onderhielden vriendschappelijke, affectieve en zelfs seksuele betrekkingen met andere mannen, zoals in detentiecentra in het algemeen gebruikelijk was.

In wat volgt, hebben we het over drie specifieke lotgevallen: lesbische vrouwen, Joodse homoseksuelen en homoseksuelen die onder dwang bij het Duitse leger werden ingelijfd. Omdat veel archieven werden vernietigd blijft het moeilijk inschatten hoeveel lesbiennes vanwege hun seksuele geaardheid in concentratiekampen werden opgesloten. Overigens blijven er maar weinig sporen over van hun anwezigheid in de 'egister werd de vermelding 'lesbisch' steevast als addendum opgenomen, dat wil zeggen als bijkomend motief voor opsluiting, zoals Claudia Schoppmann in haar bijdrage terecht opmerkt. De informatie over homoseksuele Joden is al even fragmentarisch. ${ }^{2}$ Maar via verschillende casussen krijgen we toch een beter inzicht in de dubbele straf die hun te beurt viel. Hans Meyersohn bijvoorbeeld, gedeporteerd naar Sachsenhausen in de buurt van Berlijn, werd in 1937 door het nazigerecht veroordeeld als een persoon van het Joodse ras' die seksuele betrekkingen had onderhouden met Arische mannen. ${ }^{3} \mathrm{Op}$ zijn
(2) De bevindingen in dit deel werden deels ontleend aan een

(3) 'Strafschärffend fiel ins mit einem Avier widershn als Jud Unzucht begangen und damit das rassische Empfinden das gröblichste verletzt hat.'
(Schlagdenhauffen 2006, 172) 
proces werd hij twee keer beschuldigd, eenmaal van homoseksualiteit en eenmaal van raciale smaad aan het Duits volk. In de uitspraak van het arrest op 3 februari 1937 werd het Joodse 'karakte van de homoseksueel Hans Meyersoh een verzwarende factor genoemd. Vervolgens werd hij opgesloten in Sachsenhausen. Net als alle homoseksuele Joden werd hij in quarantaine geplaats in het blok van de homoseksuelen, e dus niet samen met de andere Joden in het 'kleine kamp'. Dit geval is bijzonder interessant, omdat de nazi's voor mannen met een dubbel brandmerk een uitzondering maakten. Zodra het on homoseksuelen ging, of die nu 'Arisch' dan wel 'Joods' waren, werden ze in dezelfde barakken samengebracht on te vermijden dat homoseksualiteit zic naar de rest van het kamp zou 'verspreden'. Maar in bepaalde omstandighede konden homoseksuelen toch worde vrijgelaten, in het bijzonder toen Duitsland de totale oorlog aanging en elk man er toe deed.

In dit verband is het voorbeeld va Heinz F. veelbetekenend. Hij werd maa bij de Wehrmacht ingelijfd nadat hijverschillende kampen had aangedaan. Zijnbiografie, opgetekend door Rainer Hoffschildt in een boek over homoseksuelen in Hannover, is de moeite waard on even bij stil te staan (Hoffschildt 1992 130-133). Heinz F. werd in 1905 gebore en ging na zijn eindexamen middelbar school rechten studeren. Vervolgen vestigde hij zich in München, waa hij een homoseksuele vriendenkring opbouwde. Op 17 december 1935 wer hij door de Gestapo gearresteerd. Zij aanhouding, net als die van twintig andere vermeende homoseksuelen, volgde op de aanhouding van een kennis. Heinz F. werd eerst opgesloten in de gevangenis van Bielefeld, vervolgen werd hij overgebracht naar de gevan- genis in München en uiteindelijk naar Dachau, waar hij twee jaar bleef. In jul 1937 werd hij vrijgelaten. Een jaar late werd hij weer gearresteerd en gevan gengezet. Het motief voor de tweede aanhouding is niet bekend. Ditmaa werd hij opgesloten in Buchenwald, waar hij tot 1942 bleef. Hij werd er ingedeeld bij de penitentiaire compagnie, maar beweerde geluk te hebben gehad, want hij werkte als vergruizer. Samen met een andere, Berlijnse homoseksueel vulde hij kiepwagentjes met stenen uit een steengroeve. In 1942 werd hij overgebracht naar Natzweiler. Die periode was naar eigen zeggen de zwaarste. Aan het eind van 1942 werd hij opnieuw overgeplaatst, nu naar Sachsenhausen Op dat ogenblik hadden de industrieën die profiteerden van de concentratiekampgevangenen extra mankrach nodig. Om die reden ontsnapte Heinz F. aan het disciplinaire commando en hijwerd toegewezen aan een werkplaat van het luchtvaartbedrijf Heinkel. Eind 1944 beval de Gestapo dat hij uit he kamp moest worden vrijgelaten en overgebracht naar de gevangenis van München. Op 1 mei 1945 werd hij ingelijfd bij de Wehrmacht. Het betreft geen alleen staand geval, want eind 1944 werden alleen al in Sachsenhausen 357 andere gevangenen vrijgelaten en onmiddellijk naar het front gestuurd (Calic 2012).

\section{Verzet, vrijhedlen en progressieve wetgeving}

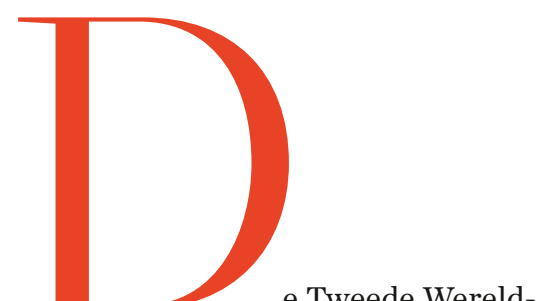
oorlog was niet alleen een tijd waarin homoseksuelen werden vervolgd, de periode vormde ook een hoogtepunt van de strijd tegen het nazisme. Ee aantal homoseksuele vrouwen en mannen onderscheidden zich op dat vlak. Bovendien, en dit zal verderop worde uitgediept, voerden bepaalde Europese anden progressieve hervormingen uit ter bescherming van homoseksuelen. Heel wat biseksuele en homoseksuele mannen en vrouwen engageerde zich in verzetsbewegingen. In Frankrijk is er het voorbeeld van Daniel Cordier, die in 1942-1943 secretaris was van Jean Moulin [een van de belangrijkste Franse verzetslui (1899-1943), noo van de vertaler]. Daarnaast ook Pasca Copeau, een van de oprichters van de Conseil National dela Résistance (Leenhardt 1994), en de lesbische kunstenares Claude Cahun die samen met haa metgezel actief meewerkte aan verzetsbewegingen op het eland Jersey, tot ze in 1944 door de Gestapo werd opgepakt.
Met de historicus Michael Sibalis kunnen we zelfs de werkhypothese opperen dat homoseksuelen ideale verzetslui waren. Zewarenimmers 'eraan gewend " gaans eega noch kinderen, waardoor ze makkelijker 'die sprong in het niets wagen die nu eenmaal inherent is aan verzet' (Jackson 2007).

Een groot stuk van de geschiedenis van de homoseksuelen in het verzet moet nog worden geschreven. Momenteel zijn slechts een paar versnipperde elementen bekend. De Tsjechische historicus Jan Seidl bijvoorbeeld vond sporen van Tsjechische homoseksuelen en lestiennes binnen verzetsnetwerken Ten eerste was er het netwerk rond de priester Otakar Zadražil (1900-1945), een geestelijke van het augustijnenklooster in Brno. Ten tweede een stel vrouwen dat in Praag een netwerk oprichtten van uitsluitend homoseksuelen (mannen en vrouwen). Uit de fragmentarische bronnen leren we dat de groep werd gearresteerd en gedeporteerd als politiek gevangenen (Seidl 2014, 263-264)

Florence Tamagne, auteur van een opmerkelijke bijdrage in dit dossier, wist in eerder onderzoek al aan te tonen dat homoseksuelen zich zelfs onderscheidden in verzetsnetwerken binnen de concentratiekampen. Een van hen was Robert Oelbermann, leidervan een door de nazi's verboden jeugdbeweging. Hij werd beschuldigd van misdaden tegen artikel 175 en in september 1936 veroordeeld tot 21 maanden dwangarbeid (vgl Tamagne 2006). Andreas Sternweiler schrijft over de man:

In Sachsenhausen organiseerde hij een verzetsgroep waarin hij homoseksuelen en politieke gevangenen wist te verenigen. [...] Na de oorlog washij een van de weinige homosek- 
suele gedeporteerden die voor hun politieke engagement de status van 'oorlogsslachtoffer' kregen. (Sternweiler 2000)

Tijdens de Tweede Wereldoor log werden tegelijkertijd veel wette gestemd die homoseksuelen juist moes beschermen. Sommige Europese landen haalden homoseksuele relatie uit de strafrechtelijke sfeer, te beginnen met IJsland in 1940. Het stemde zijn wetgeving daarmee af op die van Denemarken, waar dit al in 1933 was gebeurd. In 1942 maakte het invoere van een nieuw federaal strafweetboek in Zwitserland deel uit van diezelfde dynamiek om het seksuele recht te moderniseren. In dat land hadden de Zwitsers-Duitse kantons homoseksualiteit tot dan toe meestal bestraft op basis van het Duitse artikel 175, terwij de Latijnse kantons grotendeels het Franse of Italiaanse recht overnamen, waarin homoseksualiteit niet verbode was. Het laatste Europese land dat de weg van de decriminalisering insloeg was Zweden in 1944. De voorstander van de hervorming meenden dat op die manier de afpersers die het voora op homoseksuelen gemunt hadden, de pas kon worden afgesneden. Zoals uit de geschiedenis is gebleken breidde die tendens van geleidelijke decriminalisering en erkenning van homoseksuele levensvormen, hoofdzakelijk gedreve door Scandinavische en neutrale staten, zich na de oorlog over heel Europa uit. De geschiedenis van de Europese homoseksuelen tijdens de Tweed Wereldoorlog is nog lang niet geschreven. We hebben jonge, stoutmoedige onderzoekers nodig om een aanta nieuwe pistes te bestuderen en ander verder uit te werken. Met dit themabij. Het dossier biedt diepgaande inzich- ten van ervaren vorsers met naam en faam in het domein, maar presenteert ook in primeur de eerste resultaten van gloednieuwe publicaties van jonge onderzoekers.

\section{Régis Schlagdenhauffe} Vertaling withet Frans: Gorikde Henau
BIBLIOGRAFIE

- Daniel Arsand, Je suis en vie et tu ne méntends pas, Arles: Actes Sud,

- Mickaël Bertrand, La déportation pour motif d'homosexualité en France,

Edouard Calic, Himmler et l'empire SS, Parijs: Nouveau Monde, 2012 - Olivier Charneux, Les guérir, Parijis: Robert Laffont 2016. - Günter Grau, Homosexualität in der NS-Zeitt. Dokumente einer
Diskriminierung und Verfolgung, Frankfurt: Fischer, 2004.

- Kai Hammermeister, Inventing History: Toward a Gay Holocaust
Literature The German Quaterly 70(1) 1997, 18-26. - Heinz Heger, De mannen met de roze driehoek: het verslag van een homoseksueel over zijp gevangenschap in het concentratiekamp van 1939
tot 1945 [1972], uit het Duits vertaald door A. J. Gerritsen, Amsterdam: Pegasus, 1982 .

- Rainer Hoffschildt, 'Wegen Homosexualität beinahe zehn Jahre in Konzentrationslagern - das Bericht eines Zeitzeugene', in id., Ollivia. Die
bisher geheime Geschichte des Tabus Homosexualität und der Verfolgun - Julian Jackson, 'Lhomosexualité au XXe siècle: climats, problèmes' (geraadpleegd 31 juli 2017).

- Burhard Jellonek, Homosexuelle unter dem Hakenkreuz. Die Verfolgung
von Homosexuellen im Dritten Reich, Paderborn: Schöningh, 1990. - Johann Karl Kirchknopff 'AAnschluss, une annexion sexuelle?', in Régis
Schlagdenhauffen Julie Le Gac \& \& Fabrice Virgili (red.). Homosexuelle-s en Europe au temps de la Seconde Guerre mondiale, Parijs: Nouveau

- Pieter Koenders, Tussen christelijik reveil en seksuele revolutie. Bestrijding van zedeloosheid, met de
Amsterdam: IISG, 1996.

--.-. 'Die Bekämpfung der Homosexualität in den besetzten Nationalsozialistischer Terror gegen Homosexuelle. Verdrängt und

- Rüdiger Lautmann, Seminar: Gesellschaft und Homosexualität.

- Rüdiger Lautmann, Seminar: Gesellsc
Frankfurt-am-Main: Suhrkamp, 1977.

- Pierre Leenhardt, Pascal Copeau: 1908-1982: I'histoire préfere les
Angela Mayer, “Schwachsinn höheren Grades". Zur Verfolgung
lesbischer Frauen in Österreich während der NS-Zeit, in Burkhard Jellonek \& Rüdiger Lautmann (red.), Nationalsozialistischer Terror gegen Homosexuelle. Verdrängt und ungesühnt, Paderborn: Ferdinand
Schöningh, 2002, 83-96. - Olaf Mufimmann (red.), Homosexuelle in Konzentrationslagern, Bad
Münsterefelel: Westkreuz, 2000. - Thomas Rahe (red.), Beiträge zur Geschichte der nationalsozialistische Verfolgung in Norddeutschland Verfolgung von
Nationalsozialissus, Bremen: Temmen, 1999 .

- Thomas Rozec, Le Il/ Reich et les homosexuels, Parijs: Hermann, 2011 - Régis Schlagdenhauffen, 'Le nouveau musée de Yad Vashem et la commémoration des victimes homosexuelles du nazisme' [2005],
Bulletin du Centre de recherch français de Jérusalem 16, 2006, 120-138. ---, Triangle rose, Parijs: Autrement, 2011.

herdenking van de slankhng aan het Homors van het nazirirumenent in Amsterdam: van de herinnering', vertaald dit het Frans door Anneleen Spiessens,
Getuigen tussen geschiedenis en gedachtenis 110, 2011, 114-126. -..., Julie Le Gac \& Fabrice Virgili (red.), Homosexuel-le-s en Europe
pendant la Seconde Guerre mondiale, Pariji: Nouveau Monde, 2017.

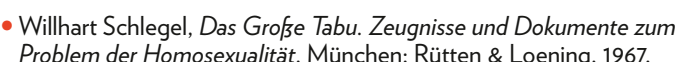
- Claudia Schoppmann, Nationalsozialistische Sexualpolitik und weibliche

- Jean-Luc Schwab, Rudolf Brazda. Itinéraire d'un triangle rose, Parijs:
Florent Massot, 2010 .

Pierre Seel \& Jean Le Bitoux, Moi Pierre Seel, déporté homosexuel,
Parij: Calmann-Lévy, 1994.

Jan Seidl, Ruth Jochanan Weiniger, Ladislav Zigkmund \& Lukáš Nozar (red.), Tepla Praha. Pruvodce po

Andreas Sternweiler, 'Homosexuelle aus der Jugendbewegung', in
Joachim Müller \& Andreas Sternweiler, Homosexuelle Männer im KZ Sachsenhhuusen, Berlijn: Schwules Museum/Rosa Winkel, 2000, 109-144. - Florence Tamagne, 'La déportation des homosexuels durant la Second
Guerre mondiale', Revue déthique et de théologie morale 239, 2006,
77-104. 